\title{
Vascular Epiphytes in Doshke and Kurpaye: A Comparative Study, Gamo Gofa, Ethiopia
}

\author{
Zeleke Assefa Getaneh and Feleke Woldeyes Gamo \\ Department of Biology, Arba Minch University, P.O. Box 21, Arba Minch, Ethiopia \\ Correspondence should be addressed to Zeleke Assefa Getaneh; zelekepg@gmail.com
}

Received 23 December 2015; Accepted 4 April 2016

Academic Editor: Alexandre Sebbenn

Copyright (c) 2016 Z. A. Getaneh and F. W. Gamo. This is an open access article distributed under the Creative Commons Attribution License, which permits unrestricted use, distribution, and reproduction in any medium, provided the original work is properly cited.

\begin{abstract}
Epiphytes comprise about $10 \%$ of the world's total flora. However, the survival of these important elements of the global vegetation is recognized to be increasingly threatened, and surveys made to study them remain far from being complete. This study has focused on investigating the vascular epiphytes (true epiphytes, hemiepiphytes, and accidental epiphytes) in Doshke and Kurpaye forests of Gamo Gofa zone, southwest Ethiopia. A total of 40 (20 in each) $25 \mathrm{~m} \times 25 \mathrm{~m}$ quadrats were established along four line transects for vegetation data collection. A total of 35 species of vascular epiphytes were recorded in the two sites (22 and 14 species from Doshke and Kurpaye, resp.). Drynaria volkensii was the only species to be recorded from the two sites. Doshke and Kurpaye forests also varied in the number of phorophytes (17 and 10 phorophytes species, resp.). The richest epiphyte family of Doshke is Orchidaceae ( 5 species) and that of Kurpaye is Polypodiaceae ( 3 species) while Orchidaceae dominate the combined flora being represented by 7 species. In terms of vertical distribution, most species were located at the canopy area. Most vascular epiphytes showed no preference for host trees except for a few species which exhibited higher occurrence rates on the host plant species Syzygium guineense, Schrebera alata, and Acacia tortilis. Vascular epiphyte abundance and species richness were both significantly positively correlated with host tree size. Vascular epiphytes of the studied forests are under a serious pressure, mainly due to anthropogenic activities, and this may lead to their local extinction.
\end{abstract}

\section{Introduction}

Epiphytes, organisms living on a plant or in the dead outer tissues of a plant without drawing water or food from its living tissues [1], are important elements of the world flora constituting about $10 \%$ of all plant species [2]. These plants have evolved into many unrelated taxa around the world [3] and are particularly well recognized members of tropical forest ecosystems where they comprise a significant proportion (as much as 50\%) of plant species [4].

Epiphytes are not evenly distributed around the world. The highest epiphyte diversity occurs in the tropics, especially in perhumid midelevation mountain forests $[3,5]$. This is associated with the complexity and variability of microhabitats available in the region. Within the tropics, the diversity center of epiphytes is clearly located in the Neotropical region while Africa is considered as being comparably poor in epiphytes and tropical Asia takes an intermediate position [3].
Epiphytes have important ecological values and contribution to forest biodiversity such as increasing species diversity, primary productivity, biomass, litter fall, and water retention, and they also provide substrate for nitrogen fixing bacteria. Vascular epiphytes also provide essential habitat and food for canopy dwelling fauna and serve as indicators of change in microclimate as well as global climatic change $[4,6]$. In addition, epiphytes increase the surface area of phorophytes for interception of water and nutrients during precipitation events. Thus, epiphytes can expand both the nutrient storage and absorption capacity of tropical and subtropical forest ecosystems [7].

The diversity and distribution of vascular epiphytes are determined by many factors. The biophysical environment of phorophytes (such as host size, bark texture, and vertical stratification) and elevation above sea level, disturbance, and climatic factors are among the major factors [2]. Large trunks have more surface area to be colonized by epiphytes 
compared to small trees [8]. Rough bark texture of the phorophytes is similarly more convenient for vascular epiphyte species establishment compared to smooth ones [9]. Vertical distribution of epiphyte indicated that diversity increases from the base of the host plants through trunk to the crown.

As Lowman [10] indicated, relatively little is known about epiphytes in contrast to the plants terrestrial counterparts because of their location high above the forest floor and the methodological difficulties faced to sample them. In other words, low accessibility of source habitats contributed to relatively less investigation of the plant group [11]. The innovation of canopy access techniques such as rope climbing, walkways, platforms, cranes, and hot-air balloons today, however, resulted in a growing interest in canopy research though these methods are still not easily available for native researchers of developing countries [12]. As a result, there has been limited effort of documenting the epiphyte flora of the supposedly epiphyte-rich tropical forest ecosystems.

Ethiopia is one of the countries where studies on epiphytes have been very rare. As Alemayehu [13] indicated in a study from southeast Ethiopia, there is an obvious lack of information on these plant groups in the country. Tafa [14] who conducted a similar study on the plant groups in southwest Ethiopian forest also noted that there still a lack of enthusiasm to study epiphytes in Ethiopian forest ecosystems. The unfortunate situation appears to have originated from the less conspicuous nature of epiphytes that hindered gaining attention and the associated lack of awareness about the roles of the plant groups. This study, which was conducted in Doshke and Kurpaye forests of Gamo Gofa zone in southwest Ethiopia, is hoped to help in envisaging a wider scope in plant-related research in the country. The study was conducted with the aim of generating data on epiphytes so as to contribute to a better understanding of these plant groups.

\section{Materials and Methods}

2.1. Study Area. Doshke and Kurpaye forests are located in Gamo Gofa, Zone of Southern Nations, Nationalities, and Peoples Regional State (SNNPRS) (Figure 1). Doshke forest $\left(6^{\circ} 11^{\prime} 48^{\prime \prime}-6^{\circ} 12^{\prime} 23^{\prime \prime} \mathrm{N}\right.$ and $\left.37^{\circ} 33^{\prime} 06^{\prime \prime}-37^{\circ} 33^{\prime} 53^{\prime \prime} \mathrm{E}\right)$ is a small forest patches in Chencha Wereda close to Dorze town on the northwest direction. It ranges in altitude from $2425 \mathrm{~m}$. to 2550 m.a.s.l and covers an area of about 110 hectares. On the other hand, Kurpaye forest $\left(6^{\circ} 08^{\prime} 30^{\prime \prime}-6^{\circ} 08^{\prime} 53^{\prime \prime} \mathrm{N}\right.$ and $\left.37^{\circ} 34^{\prime} 41^{\prime \prime}-37^{\circ} 34^{\prime} 72^{\prime \prime} \mathrm{E}\right)$ is part of the highland vegetation in Ocholo Kebele of Arba Minch Zuriya Wereda on the way from Arba Minch to Dorze town. The vegetation, which mainly occupies escarpments of an extended gorge, covers an area ranging in altitude from $1632 \mathrm{~m}$ to 1810 m.a.s.l.

2.2. Data Collection. A reconnaissance survey was made in order to obtain an impression of the site conditions, to collect information on accessibility, and to select sampling design. Following this, four transects ( 2 in each forest) covering the whole ranges of altitude were laid. The GPS navigation system was used to locate the transects on the ground. A total of 40 (20 in each study site) $25 \mathrm{~m} \times 25 \mathrm{~m}$ quadrats were systematically established at an interval of 200 meters following the method used by Hietz and Hietz-Seifert [15].

Vegetation data collection in each quadrate was started by preferential selection of three to four large trees of a single species with $\mathrm{DBH} \geq 10 \mathrm{~cm}$ and that seemed safe to climb (i.e., with no obvious sign of branch rot) and also contained more epiphytes. The rational for considering tree species with $\mathrm{DBH} \geq 10 \mathrm{~cm}$ as appropriate host for sampling epiphytes is that phorophytes with $\mathrm{DBH}$ less than $10 \mathrm{~cm}$ provide smaller surface area and thus hold either very few numbers of or no vascular epiphyte species [15]. Following selection of host trees, sampling and recording of epiphyte species on phorophytes (host trees), counting the number of individuals of each epiphyte species on a phorophyte, determining the exact location of epiphytes on the phorophyte, observations on distributional variation of epiphytes on host trees of different DBH classes, and assessment of the canopy cover status (with respect to light penetration) were carried out.

The life-forms of the vascular epiphytes were described according to Bogh [16], which included true epiphytes (T), species that normally spend their entire life span as epiphytes; hemiepiphytes $(\mathrm{H})$, species that germinate on trees and later establish root contact with the ground; and accidental epiphytes, predominantly terrestrial plants that accidentally germinate in the tree trunk crevices. Sample collection and recording of vascular epiphyte species were performed with the help of local assistants skilled in climbing trees while identification and counting of well-developed epiphytes occurring high up in the canopies/crown were done with the aid of binoculars. The number of vascular epiphytes on each phorophyte was counted following an established method $[2,17]$. Accordingly, those epiphytes occurring in dense stands were counted as a single individual. The vertical distribution of vascular epiphytes on the phorophytes was studied following Mojiol et al. [18] zonation. Accordingly, host trees were partitioned into three zones: (1) basal region, from the ground to the diameter at breast height (at or below $3 \mathrm{~m}$ above ground level); (2) trunk region, from diameter at breast height (to the first branch/above $3 \mathrm{~m}$ and below the first branch); and (3) canopy region, from first branch to tip of the tree.

Voucher specimens of both vascular epiphyte species and phorophyte plant species were collected, pressed, dried, and identified at the National Herbarium of Addis Ababa University, ETH, through referring to the existing publications of floras of Ethiopia and Eritrea.

2.3. Data Analysis. To test similarities and differences among vascular epiphytes of the two forests, multivariate analyses have been performed and their pattern of vertical distribution on host plants with host $\mathrm{DBH} \geq 10 \mathrm{~cm}$ was carried out. The correlation between size of host tree and the numbers of epiphyte species inhabiting the host was analyzed using regression-correlation by employing the SPSS, version 17 . The diversity of vascular epiphytes in the two forests was analyzed using Shannon-Weiner diversity and evenness indices following Shannon and Weaver [19] as follows: $H^{\prime}=-\sum_{i=1}^{S} p i \ln p i$, where $H^{\prime}$ is Shannon-Wiener indices of diversity, $S$ is number of species, $p i$ is proportion of the $i$ th species which is $n i / N$, 


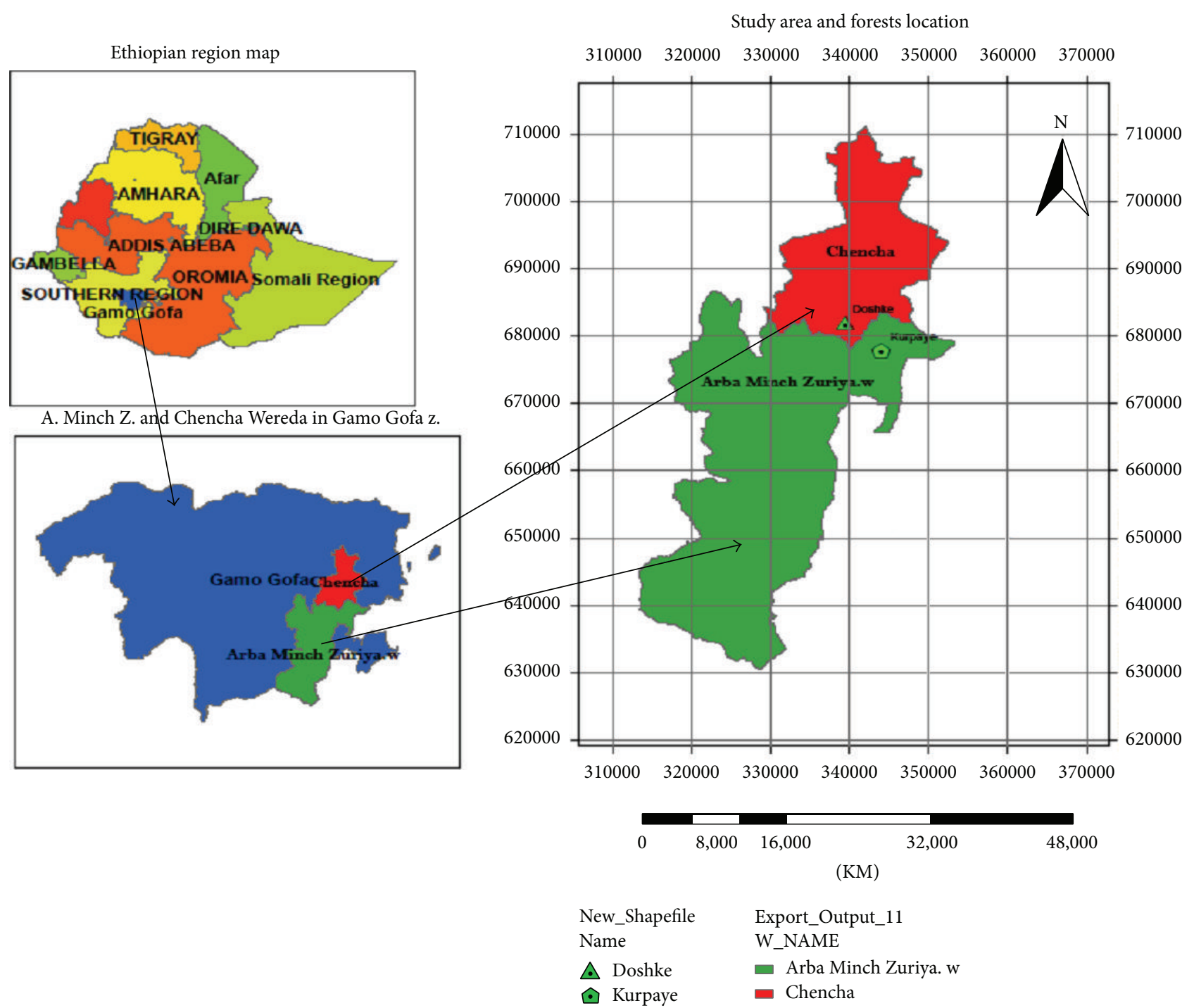

Figure 1: Map of the study area.

$n i$ is number of individuals of species $i$, and $N$ is total number of individuals. On the other hand, evenness $(E)$ was computed as $E=H^{\prime} / H^{\prime} \max$, where $H^{\prime}$ max is ln (natural logarithm) of $S$ (number of species). Floristic similarities of both epiphyte species and host plant species of the two forests were calculated by employing Sorensen's similarity coefficient [20] by using the following equation: $\mathrm{Ss}=2 a /(2 a+b+c)$, where Ss is Sorensen's similarity coefficient, $a$ is number of species common to both samples, $b$ is number of species in sample 1 , and $c$ is number of species in sample 2 .

\section{Results}

3.1. Vascular Epiphytes Diversity. A total of 35 species of vascular epiphytes (21 from Doshke, 13 from Kurpaye, and 1 from both) belonging to 24 families have been recorded from the study sites (Tables 3 and 4).

The recorded vascular epiphytes belonged to the three life-forms established in Materials and Methods: accidental epiphytes, hemiepiphytes, and true epiphytes (holoepiphytes). Of these, accidental epiphytes have constituted about $31.4 \%$ (11 species), hemiepiphytes have constituted about $5.7 \%$ ( 2 species), and true epiphytes have constituted about $62.8 \%$ (22 species) (Table 1). The hemiepiphytes are represented by two families (Araliaceae and Urticaceae), whereas the true epiphytes and the accidental epiphytes are represented by twelve and ten families, respectively.

On the other hand, the sampled 368 host trees (phorophytes) were found to represent 36 species that belonged to 24 families. At individual study area level, Doshke and Kurpaye contributed 20 and 19 species, respectively, with Allophylus abyssinicus, Ficus sur, and Syzygium guineense being commonly shared. Out of the total hot trees sampled, 266 (72.3\%) individual trees hosted epiphytes while the remaining $102(27.7 \%)$ did not host epiphytes. Moraceae is the most epiphyte hosting family represented by 4 species followed by Araliaceae which is represented by 3 species. 
TABLE 1: Epiphyte species recorded from the study sites.

\begin{tabular}{lcc}
\hline Accidental epiphytes & Hemiepiphytes & True epiphytes \\
\hline Achyranthes aspera & Schefflera myriantha & Drynaria volkensii \\
Bersama abyssinica & Urera hypselodendron & Aerangis brachycarpa \\
Clausena anisata & Aerangis luteoalba & Elaphoglossum lostii \\
Commelina foliacea & Amauropelta bergiana & Eulophia petersii \\
Ficus ovata & Arthropteris orientalis & Huperzia ophioglossoides \\
Ficus sycomorus & Asplenium cf. bugoiense & Liparis deistelii \\
Impatiens tinctoria & Asplenium smedsii & Loxogramme abyssinica \\
Jasminum abyssinicum & Asplenium theciferum & Oncocalyx fischerii \\
Pappea capensis & Canarina eminii & Peperomia abyssinica \\
Pycnostachys meyeri & Coniogramme africana & Polystachya caduca \\
Rhus natalensis & Diaphananthe schimperiana & Stolzia repens \\
\hline
\end{tabular}

TABle 2: Diversity and evenness of vascular epiphytes in the two forests.

\begin{tabular}{lcc}
\hline & Doshke & Kurpaye \\
\hline Shannon-Weiner diversity $\left(H^{\prime}\right)$ & 2.2 & 1.59 \\
Evenness $(E)$ & 0.72 & 0.61 \\
\hline
\end{tabular}

The number of vascular epiphytes recorded from a single plant species sampled in the study varied from zero to 16 . Accordingly, the highest richness was recorded from Syzygium guineense (16 species), Schefflera myriantha (11 species), and Maytenus undata (10 species). Plant species that were found to bear no vascular epiphytes were Euphorbia ampliphyla, Hagenia abyssinica, and Maesa lanceolata.

As indicated (Table 2), epiphyte diversity and evenness measures yielded different values for the two forests. While Doshke forest exhibited the higher $H^{\prime}$ and $E$ values, Kurpaye forest showed the lower values of $H^{\prime}$ and $E$.

3.2. Vertical Distribution of Epiphytes on Phorophytes. Vascular epiphytes of the studied sites were found to be distributed in the different zones of the host plants. Accordingly, 10, 14, and 16 epiphyte species of Doshke inhabited base, trunk, and canopy regions, respectively, while 9,13 , and 5 epiphyte species were recorded from the three regions in the given order in Kurpaye (Tables 5 and 6).

As the distributional pattern revealed, vascular epiphyte species Asplenium smedsii, Elaphoglossum lostii, Peperomia abyssinica, and Urera hypselodendron grow in all the three regions of phorophytes; Asplenium cf. bugoiense, Asplenium theciferum, and Pycnostachys meyeri were found on base and trunk portions of the phorophytes whereas Canarina eminii, Diaphananthe schimperiana, Dorstenia barnimiana, Drynaria volkensii, Coniogramme africana, Liparis deistelii, and Schefflera myriantha were occupying trunk and canopy portions of the phorophytes. On the other hand, some species of vascular epiphytes such as Achyranthes aspera and Bersama abyssinica were restricted to the basal region as well as Huperzia ophioglossoide and Vittaria volkensii; Stolzia repens and Polystachya caduca inhabit the canopy region of the phorophytes.
3.3. Correlation between Phorophyte Size and Epiphyte Number. An analysis made to see for any association between size of host tree and diversity of epiphyte species inhabiting the host proved the existence of a positive correlation. Accordingly, a regression analysis showed that $\mathrm{DBH}$ of phorophytes and number of vascular epiphytic species are significantly related in almost a linear fashion $\left(R^{2}=0.90\right.$ and 0.66 for Doshke and Kurpaye, resp., $p=0.01$ ). Similarly, a scatter plot showed that there is a linear relationship between number of epiphyte species and host sizes (Figures 2(a) and 2(b)).

3.4. Host Specificity of Vascular Epiphytes. Out of 35 species of vascular epiphytes recorded from the study sites, 32 (91.4\%) species were recorded from 2 to 12 species of phorophytes while only 3 (8.6\%) epiphytes species were recorded from specific host tree species (Figure 3). Accordingly, the epiphytes Huperzia ophioglossoide and Vittaria volkensii were recorded only from the phorophyte species Syzygium guineense in Doshke whereas the epiphytes Aerangis brachycarpa and Oncocalyx fischerii were recorded from the phorophyte species Schrebera alata and Acacia tortilis, respectively.

3.5. Floristic Similarities of Epiphytes and Phorophytes of the Two Forests. Floristic similarities of both epiphyte species and host plant species of the two forests were calculated by using Sorensen's similarity coefficient. Accordingly, while floristic similarity of epiphytes of the two forests was found to be 0.03 , that of phorophytes was determined to be 0.07 .

\section{Discussion}

4.1. Epiphyte Diversity. As indicated in the Results, a total of 35 species of vascular epiphytes were recorded from the two study sites. Among these, 21 (60\%) species occurred only in Doshke forest, and 13 (37.1\%) species occurred only in Kurpaye forest with only one species (Drynaria volkensii) recorded from both forests.

While earlier studies conducted on Ethiopian forests Yayu [14] and Harenna [13] yielded 36 and 55 epiphyte species, respectively, Schneider [21] reported 191 epiphytes from an Andean forest in Venezuela. The record from the Venezuelan forest indicates a pronounced difference in epiphytic diversity 
TABLE 3: List of vascular epiphytic plant species in Doshke forest.

\begin{tabular}{|c|c|c|c|c|}
\hline No. & Scientific name & Local name & Family & Life form \\
\hline 1 & Achyranthes aspera $\mathrm{L}$. & Dorka & Amaranthaceae & $\mathrm{AE}$ \\
\hline 2 & Asplenium cf. bugoiense Hieron. & Bista (tinishu) & Aspleniaceae & $\mathrm{TE}$ \\
\hline 3 & Asplenium smedsii Pic. Serm. & Bista (tinishu) & Aspleniaceae & TE \\
\hline 4 & Asplenium theciferum (Kunth.) Mett. & Bista (tinishu) & Aspleniaceae & $\mathrm{TE}$ \\
\hline 5 & Bersama abyssinica Fresen. & Margite & Melianthaceae & $\mathrm{AE}$ \\
\hline 6 & Canarina eminii Ascherers ex A. Weinnif & Kulikulanto & Campanulaceae & $\mathrm{TE}$ \\
\hline 7 & Coniogramme africana Hieron. & & Hemionitidaceae & $\mathrm{TE}$ \\
\hline 8 & Diaphananthe schimperiana (A. Rich.) Summerh & & Orchidaceae & $\mathrm{TE}$ \\
\hline 9 & Dorstenia barnimiana Schweinf & & Moraceae & $\mathrm{TE}$ \\
\hline 10 & Drynaria volkensii Hieron. & Bista (tiliku) & Polypodiaceae & TE \\
\hline 11 & Elaphoglossum lostii (L.) Christ & & Lomariopsidaceae & $\mathrm{TE}$ \\
\hline 12 & Eulophia petersii Rchb. f. & & Orchidaceae & TE \\
\hline 13 & Huperzia ophioglossoides Lam. Rothm. & & Lycopodiaceae & $\mathrm{TE}$ \\
\hline 14 & Impatiens tinctoria A. Rich. & Holsoso & Balsaminaceae & $\mathrm{AE}$ \\
\hline 15 & Liparis deistelii Schltr. & & Orchidaceae & $\mathrm{TE}$ \\
\hline 16 & Peperomia abyssinica Miq. & Mulmula & Piperaceae & $\mathrm{TE}$ \\
\hline 17 & Polystachya caduca Rchb. f. & & Orchidaceae & $\mathrm{TE}$ \\
\hline 18 & Pycnostachys meyeri Gürke & Susa & Lamiaceae & $\mathrm{AE}$ \\
\hline 19 & Schefflera myriantha (Baker) Drake. & Darkatsa & Araliaceae & $\mathrm{HE}$ \\
\hline 20 & Stolzia repens (Rolfe) Summerh. & & Orchidaceae & $\mathrm{TE}$ \\
\hline 21 & Urera hypselodendron (Hochst. ex A. Rich.) & Halilo & Urticaceae & $\mathrm{HE}$ \\
\hline 22 & Vittaria volkensii Hieron. & & Vitariaceae & $\mathrm{TE}$ \\
\hline
\end{tabular}

AE: accidental epiphyte, HE: hemiepiphyte, and TE: true epiphyte.

TABLE 4: List of vascular epiphytic plant species in Kurpaye forest.

\begin{tabular}{lccc}
\hline No. & Scientific name & Local name & Family \\
\hline 1 & Aerangis brachycarpa (A. Rich.) Th. Dur. \& Schinz. & Mulmula & Orchidaceae \\
2 & Aerangis luteoalba Schltr. & & Orchidaceae \\
3 & Amauropelta bergiana (Schldl.) Holttum & Bista (tinishu) & Thelypteridaceae \\
4 & Arthropteris orientalis (Gmel.) Posth. & Bista (tinishu) & Oleandraceae \\
5 & Clausena anisata (Willd.) Hook. f. ex Benth. & Wushawusho & Rutaceae \\
6 & Commelina foliacea Chiov. & Dalesha & Commelinaceae \\
7 & Drynaria volkensii (Kunze ex Mett) J. Sm & Bista (tiliku) & Polypodiaceae \\
8 & Ficus ovate Vahl. & Made & Moraceae \\
9 & Ficus sycomorus L. & Shishaye & ME \\
10 & Jasminum abyssinicum Hoschst. ex DC. & Tsinbalo & TE \\
11 & Loxogramme abyssinica (Baker) M. G. Price. & & Oleaceae \\
12 & Oncocalyx fischerii (Engl.) M. G. Gilbert & Urmale & AE \\
13 & Pappea capensis Eckl. and Zeyh. & Shuchamache & Loranthaceae \\
14 & Rhus natalensis Brenh. & Ongafire & Sapindaceae
\end{tabular}

AE: accidental epiphyte, TE: true epiphyte, and HE: hemiepiphyte.

both with the studied two forests and with Yayu and Harenna (forests that are regarded as floristically diverse and structurally complex). This, therefore, may be taken as indicator of relatively lower epiphytic diversity in Ethiopian forests as compared to tropical forests in other regions. On the other hand, the low diversity of vascular epiphytes in Doshke and Kurpaye appears to be associated primarily with size since these forest patches are significantly smaller than Yayu and Harenna forests. Intense disturbance by humans (i.e., clearing land for farming, fuel wood collection, and timber extraction) and domestic stocks must have had their own impact as the vegetation locations are adjacent to human settlements. The negative impact of disturbance on epiphytic diversity through habitat modification was also reported in earlier studies [2, 22].

At the family level, Orchidaceae is the group that most contributes to the epiphytic diversity ( 7 out of 36 species from both sites). Prevalence of Orchidaceae appears to be a usual 


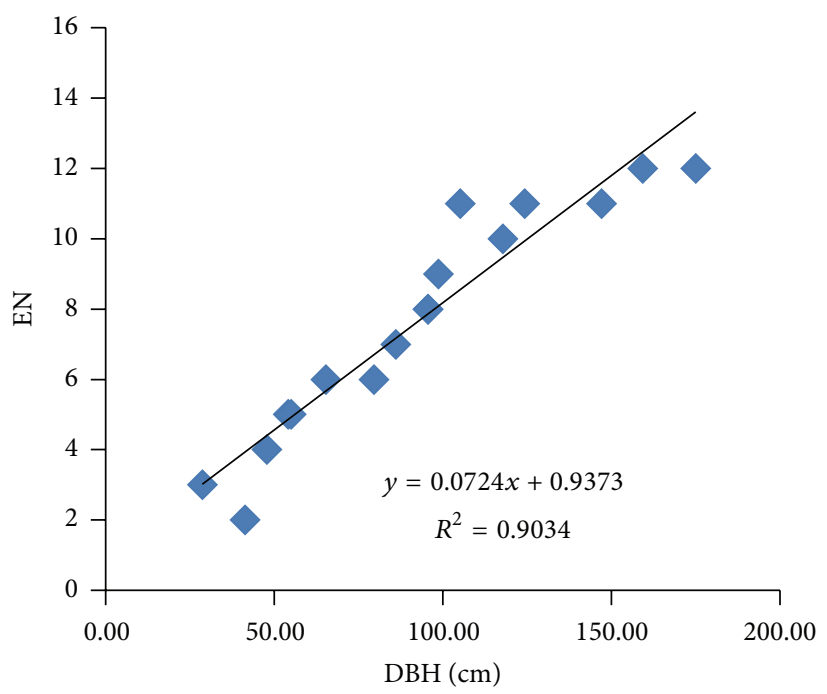

(a)

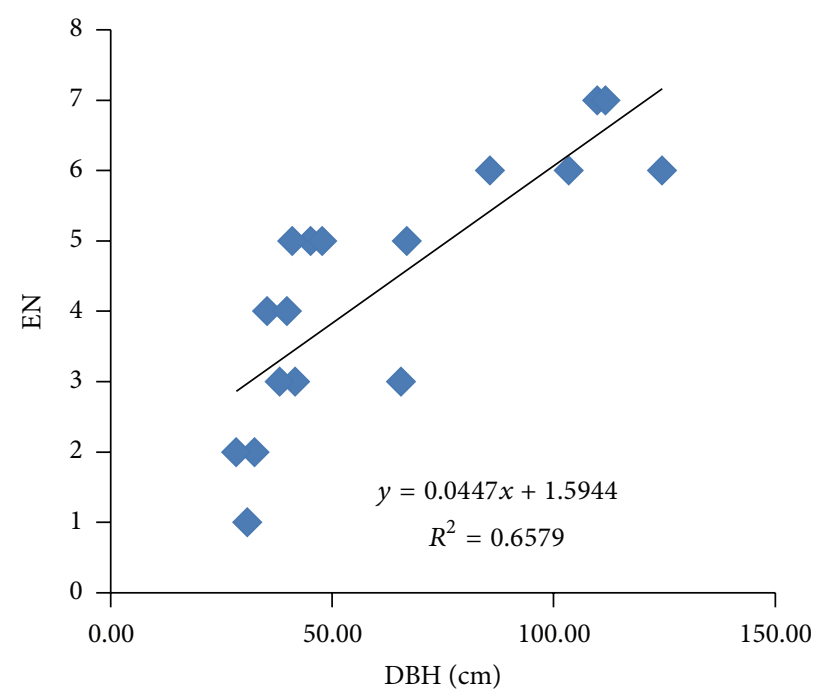

(b)

FIGURE 2: Scatter plots showing the relationship between DBH of individual phorophytes and number of vascular epiphyte species in Doshke (a) and Kurpaye (b) forests. EN = epiphytes number.

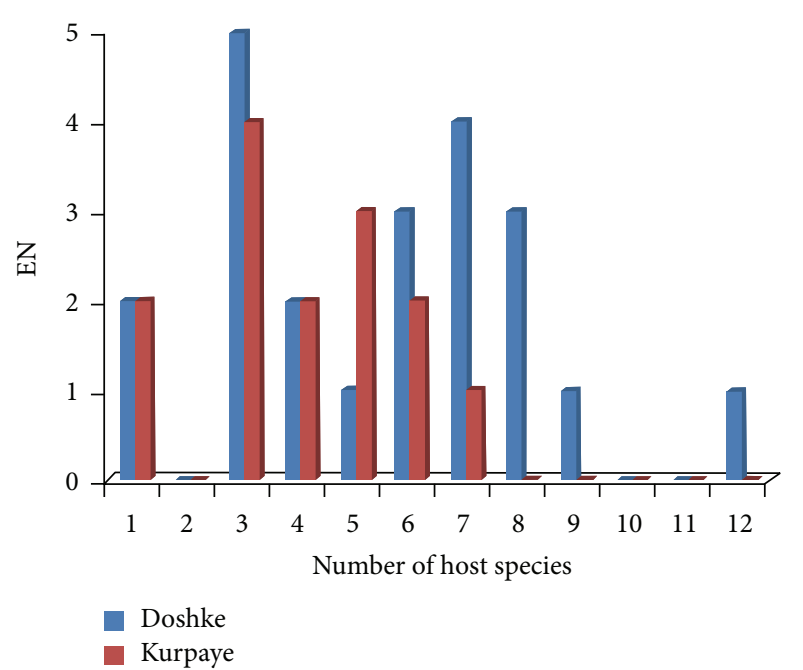

FIgURE 3: Proportion of epiphytes inhabiting 1-12 host species in the study sites. $\mathrm{EN}=$ epiphytes number.

situation as there are comparable reports from other studies. For instance, while Tafa [14] reported 20 orchid species out of 36 vascular epiphytes encountered in Yayu forest, Schuettpelz and Trapnell [23] reported 25 orchid species out of 126 epiphytes encountered in a Costa Rican forest. As indicated by Benzing [24], orchids are adapted to temporary water stress and capable of growing in drier and more sun-exposed areas of the upper canopy; and this feature might have contributed to the fair representation of Orchidaceae in the studied vegetation.

From Tables 3 and 4, the lower epiphyte species richness (14) in Kurpaye when compared to that (22) of Doshke forest is attributable to the less closed canopy nature of the Kurpaye forest as well as to the drier environmental situation as this
TABLE 5: Lists of vascular epiphytes species distributed in different zones of the phorophytes in Doshke forest.

\begin{tabular}{|c|c|c|c|c|}
\hline & \multirow{2}{*}{ Species name } & \multicolumn{3}{|c|}{ Zone of phorophyte } \\
\hline & & Base & Trunk & Canopy \\
\hline 1 & Achyranthes aspera & + & - & - \\
\hline 2 & Asplenium cf. bugoiense & + & + & - \\
\hline 3 & Asplenium smedsii & + & + & + \\
\hline 4 & Asplenium theciferum & + & + & - \\
\hline 5 & Bersama abyssinica & + & - & - \\
\hline 6 & Canarina eminii & - & + & + \\
\hline 7 & Coniogramme africana & - & + & + \\
\hline 8 & Diaphananthe schimperiana & - & + & + \\
\hline 9 & Dorstenia barnimiana & - & + & + \\
\hline 10 & Drynaria volkensii & - & + & + \\
\hline 11 & Elaphoglossum lostii & + & + & + \\
\hline 12 & Eulophia petersii & - & - & + \\
\hline 13 & Huperzia ophioglossoides & - & - & + \\
\hline 14 & Impatiens tinctoria & + & - & - \\
\hline 15 & Liparis deistelii & - & + & + \\
\hline 16 & Peperomia abyssinica & + & + & + \\
\hline 17 & Polystachya caduca & - & - & + \\
\hline 18 & Pycnostachys meyeri & + & + & - \\
\hline 19 & Schefflera myriantha & - & + & + \\
\hline 20 & Stolzia repens & - & - & + \\
\hline 21 & Urera hypselodendron & + & + & + \\
\hline \multirow[t]{2}{*}{22} & Vittaria volkensii & - & - & + \\
\hline & & 10 & 14 & 16 \\
\hline
\end{tabular}

Base $=$ ground to diameter at breast height $(\mathrm{DBH})$, trunk $=\mathrm{DBH}$ to the first branch, and Canopy $=$ first branch to the tip of the tree.

forest is situated at a lower altitude. It is recognized that dryness and more sun-exposed characteristics of disturbed 
TABLE 6: Lists of vascular epiphytes species distributed in different zones of the phorophytes in Kurpaye forest.

\begin{tabular}{lcccc}
\hline & \multirow{2}{*}{ Species name } & \multicolumn{3}{c}{ Zone of phorophyte } \\
& & Base & Trunk & Canopy \\
\hline 1 & Aerangis brachycarpa & - & + & + \\
2 & Aerangis luteoalba & - & + & + \\
3 & Amauropelta bergiana & + & + & - \\
4 & Arthropteris orientalis & + & + & - \\
5 & Clausena anisata & + & + & - \\
6 & Commelina foliacea & + & + & - \\
7 & Drynaria volkensii & - & + & + \\
8 & Ficus ovata & + & - & - \\
9 & Ficus sycomorus & + & + & - \\
10 & Jasminum abyssinicum & + & + & - \\
11 & Loxogramme abyssinica & - & + & + \\
12 & Oncocalyx fischerii & - & + & + \\
13 & Pappea capensis & + & + & - \\
14 & Rhus natalensis & + & + & - \\
\hline & & $\mathbf{9}$ & $\mathbf{1 3}$ & $\mathbf{5}$ \\
\hline
\end{tabular}

habitat result in water stress which, in turn, has negative effect on the abundance of epiphytes [2]. Differences of both forests in host species composition must have had, as noted by Benavides [25], their own role in determining the epiphytic richness of each forest as trees that grow tall have an impact on the canopy structure as well as microhabitats available for epiphytic growth [26]. Shannon-Weiner diversity $\left(H^{\prime}\right)$ and evenness $(E)$ tests that were determined for both forests also showed that Doshke forest exhibited a higher value for both indices (Table 2). This is in line with the species richness status of these forests and the greater evenness in distribution of Doshke epiphytes can be explained in terms of wetter and cooler environmental conditions, relatively better closed canopy nature, and a lesser disturbance level of the forest.

Epiphytes of Doshke and Kurpaye forests belonged to the three life-form categories and this agrees with the findings of Mucunguzi [27] from his study on diversity and distribution of vascular epiphytes in Kibale National Park, Uganda. Of the recorded three life-forms, the hemiepiphytes that belong to Araliaceae and Urticaceae were encountered only in the Doshke forest whereas the true epiphytes and the accidental epiphytes were recorded from the two study sites. Accidental epiphytes are the common life-forms in the study sites, particularly in Kurpaye forest where they comprise $50 \%$ of the total epiphyte families and true epiphytes are the most common life-forms in the study sites, particularly in Doshke forest where they comprise around $62.5 \%$ of the total epiphyte families, and this is an identical situation to what is reported from Kibale National Park (Uganda) by Mucunguzi [27].

Epiphytic floristic similarity analysis yielded Sorensen's similarity coefficient value 0.03 ; and this shows the very low similarity or significantly high difference in species composition of epiphyte of the two study sites. The observed dissimilarity in species composition of the two sites appears to be related to the difference in habitat types of the study sites.
The reported difference in species composition of epiphytes from different habitats of tropical semideciduous forest in Ghana [28] stands in favor of this argument. Drynaria volkensii turned to be the only epiphyte species shared by the two sites, and this is related to the wide altitudinal range (1200$2800 \mathrm{~m}$ ) of the species and its morphological feature which allows harvesting rain water and debris and thereby adapt to anthropogenic disturbances within the forest [29].

4.2. Vertical Distribution of Epiphytes on Phorophytes. Difference in the pattern of vertical distribution of vascular epiphyte on phorophyte was observed between the two forests. While epiphyte species richness decreased in the order of canopy-trunk-base regions in Doshke, trunk-base-canopy is the pattern in decreasing order of epiphyte species richness in Kurpaye. In both cases, the trunk region represents intermediate level of epiphyte species richness; and this is a reflection of moderate microclimatic condition and proximity to soil and exposition to wind and water falls in this part of the host plants. The contrasting results obtained in terms of species richness in the canopy region of the two forests (i.e., the most richness in Doshke and the least one in Kurpaye) relate to difference in canopy density of the two forests and moisture status of the localities. Generally, different distributional patterns of epiphytes as exemplified by their greatest concentration either on stem base [26], on trunk region [16], or toward the canopy $[23,30]$ suggest that vascular epiphytes exhibit varying distributional patterns.

Five epiphyte species of Doshke forest (Eulophia petersii, Huperzia ophioglossoides, Polystachya caduca, Stolzia repens, and Vittaria volkensii) were found to grow only in the canopy region (Table 5). These crown species may be regarded as better adapted to drier conditions and high irradiance as vascular epiphytes that inhabit the upper canopy are suggested to prefer low moisture and high light requirements [31]. Absence of such species in Kurpaye forest may be attributed to extreme drought that avoided establishment of epiphytic species adapted only to the canopy region. No epiphytic species was found to be restricted only to tree trunk. Instead, 14 species of Doshke forest and 13 species of Kurpaye forest were also found to inhabit either canopy or base or both regions of host trees. This distributional pattern may be interpreted in terms of adaptation of the species to intermediate moisture and light requirements with an additional feature of surviving at either low moisture (in those extending to the canopy) or low light (in those extending to the base) availability situations. Epiphytes restricted only to the base region of host plants include Achyranthes aspera, Bersama abyssinica, and Impatiens tinctoria in Doshke and Ficus ovate in Kurpaye. Since all of these are accidental epiphytes, their establishment in a particular part of the host plants could not be more than an accidental deposition of propagation material and a subsequent germination. Interestingly, however, Asplenium smedsii, Elaphoglossum lostii, Peperomia abyssinica, and Urera hypselodendron were found to grow in the three regions of phorophytes. This could be due to wider ecological requirements and tolerance of the species; and the epiphytes may be labeled as generalists as suggested by Johansson [17]. 
Concerning the distributional pattern of epiphytes on host plants at the life-form level, most of accidental epiphytes occupy trunk and base regions while most true epiphytes prefer trunk and canopy regions of the phorophyte. Therefore, the microclimatic aspects of the forests, among them humidity and light intensity, appear to be determining factors in the vertical distribution of epiphyte species. Thus, the spatial distribution of epiphytes indirectly reflects the quantity of resources within forests and the way in which the host trees are exploited by these epiphytic plants.

4.3. Host (Phorophyte) Size versus Epiphyte Abundance. Host tree size showed a strong positive correlation with the number of epiphyte species found on the main phorophytes of the study sites ( $r=0.950$ and $r=0.811$ for Doshke and Kurpaye, resp.). Identical results have also been reported by other authors like Burns [32]. This positive relationship between host tree size (diameter) and number of epiphyte species hosted by individual trees can be explained in terms of greater number of habitats provided by large trees compared to small trees [33], greater life span of larger trees providing more time for humus to accumulate and epiphytes to establish, and the capacity of large trees to intercept more light and water compared to small ones [34]. The positive correlation between host size and epiphyte abundance also is associated with habitat stability since epiphyte establishment, growth, and colonization are slow processes [34].

4.4. Host Specificity of Vascular Epiphytes. The result showed that most vascular epiphyte species of the study sites are not host specific. Out of the 35 epiphyte species recorded from the two sites, 31 species (88.58\%) were recorded from two or more species of phorophytes while four species of vascular epiphytes $(11.42 \%)$ were recorded from specific host tree species. This is in agreement with what Alemayehu [13] reported from his study on diversity and ecology of vascular epiphytes in Harenna Afromontane forest, Bale, Ethiopia, and Tafa [14] reported on diversity of vascular epiphytes along disturbance gradient in Yayu forest, southwest Oromia, Ethiopia, where the majority of the epiphytes (90.9\% and $86.1 \%)$, respectively, were found to be not host specific.

On the other hand, it was discovered that not all trees are equally suitable hosts for epiphytes with species Syzygium guineense and Schefflera myriantha hosting the highest number (16 and 11 species, resp.) in Doshke whereas Syzygium guineense and Ficus sur bore the most (8 and 10 epiphyte species, resp.) in Kurpaye. Variation among phorophytes with respect to the number of epiphyte species they support (despite the very little host specificity of epiphytes) appears to be a universal trend since a similar observation was made earlier by ter Steege and Cornelissen [35]. Some tree species are generally better hosts than others.

The same occurs in the studied sites. Host Species such as Hagenia abyssinica, Euphorbia ampliphyla, and Maesa lanceolata from Doshke and Mimusops kummel, Agarista salicifolia, Ficus sycomorus, Albizia grandibracteata, Combretum molle, Euclea divinorum, and Terminalia brownii from Kurpaye were poor hosts containing no vascular epiphyte species. On the other hand, host tree species such as Dracaena afromontana,
Galiniera saxifraga, Ilex mitis, Polyscias fulva, and Schefflera abyssinica from Doshke, Ficus ovata and Cordia Africana from Kurpaye, and Allophylus abyssinicus, Ficus sur, and Syzygium guineense of both Doshke and Kurpaye forests contained large number of vascular epiphyte species. This variation between vascular epiphyte species number among host tree species may be due to the characteristics of host tree species such as age and bark texture and size [8] as well as distribution of mycorrhizal fungal symbionts and other bark characteristics [24].

\section{Conclusion}

This study was intended to explore species composition and distribution of vascular epiphytes in Doshke and Kurpaye forests and to compare and contrast the similarities and differences in the species composition and distribution of vascular epiphytes between the two sites. Through the study, it was confirmed that a total of 35 vascular epiphyte species ( 21 from Doshke, 13 from Kurpaye, and 1 from both) which belong to 24 families were collected and identified. The species composition and diversity of vascular epiphytes of the two study sites were notably different from each other. This difference is attributed to the differences in the altitude at which the two forests are located and the associated environmental parameters such as moisture, light, and humidity as well as the degree of severity of forest disturbances.

The evidence from this study suggests that the Doshke forest which is located at higher altitude was found to harbor more species and higher diversity of epiphytes compared to Kurpaye forest which is located at lower altitude. The reason for this is the presence of comparatively high moisture content, frequent rainfall, and occurrence of thick, big, and old trees with canopies, low disturbance, and wetter environment. In addition to the above factors, changes in humidity that can be caused by forest disturbance leading to a more open canopy and dryer microclimatic conditions and dryer climate in the forest due to its elevation might have contributed to the observed lower epiphyte richness of Kurpaye forest.

In general, the species diversity of vascular epiphytes in the studied forests is relatively low when compared with other forests in Ethiopia and tropical forests. The result also showed that, in both forests, phorophyte tree size (DBH) has a considerable effect on the number of epiphyte species; that is, the larger the size of a phorophyte, the more the number of epiphyte species it is found to support. This indicates the importance of having giant trees in vegetation and also the associated structural complexity of forests in supporting greater epiphyte diversity. The fact that epiphytes show no special preference to host species, which is identical to other studies, may be taken as indication of lack of coevolutionary processes; and this, in turn, implies the possibility of increasing epiphyte diversity in a forest by allowing trees to sufficiently grow in height and girth. The result has also indicated the influence of anthropogenic disturbance on vascular epiphyte diversity and the necessity of forest conservation to maintain the diverse life-forms contained within it. 
Forests are primary sources of diverse resources to local people whereas epiphytes are inconspicuous, rarely noticed, and less interest attracting components of the forest. It follows then that vascular epiphyte survival is directly linked to the survival of forests. The inclusion of local communities in the forest conservation activities and management should, therefore, be considered as a realistic option to reduce the harm done to these essential ecosystems and also conserve the various vital resources (including epiphytes) that are associated with forests.

\section{Competing Interests}

The authors declare that they have no competing interests.

\section{Acknowledgments}

The authors are grateful to Arba Minch University for providing the facilities to work.

\section{References}

[1] J. J. Barkman, Phytosociology and Ecology of Cryptogamic Epiphytes, Van Gorcum, Assen, Netherlands, 1958.

[2] W. Barthlott, V. Schmit-Neuerburg, J. Nieder, and S. Engwald, "Diversity and abundance of vascular epiphytes: a comparison of secondary vegetation and primary montane rain forest in the Venezuelan Andes," Plant Ecology, vol. 152, no. 2, pp. 145-156, 2001.

[3] A. H. Gentry and C. H. Dodson, "Diversity and biogeography of neotropical vascular epiphytes," Annals of the Missouri Botanical Garden, vol. 74, no. 2, pp. 205-233, 1987.

[4] A. H. Gentry and C. Dodson, "Contribution of nontrees to species richness of a tropical rain forest," Biotropica, vol. 19, no. 2, pp. 149-156, 1987.

[5] C. L. Cardelús, R. K. Colwell, and J. E. Watkins Jr., "Vascular epiphyte distribution patterns: explaining the mid-elevation richness peak," Journal of Ecology, vol. 94, no. 1, pp. 144-156, 2006.

[6] D. H. Benzing, "Vulnerabilities of tropical forests to climate change: the significance of resident epiphytes," Climatic Change, vol. 39, no. 2-3, pp. 519-540, 1998.

[7] C.-C. Hsu, F.-W. Horng, and C.-M. Kuo, "Epiphyte biomass and nutrient capital of a moist subtropical forest in north-eastern Taiwan," Journal of Tropical Ecology, vol. 18, no. 5, pp. 659-670, 2002.

[8] G. Zotz and H. Ziegler, "The occurrence of crassulacean acid metabolism among vascular epiphytes from Central Panama," New Phytologist, vol. 137, no. 2, pp. 223-229, 1997.

[9] N. M. Nadkarni, "Colonization of stripped branch surfaces by epiphytes in a lower montane cloud forest, Monteverde, Costa Rica," Biotropica, vol. 32, no. 2, pp. 358-363, 2000.

[10] M. D. Lowman, Life in the Tree Tops, Yale University Press, New Haven, Conn, USA, 1999.

[11] H. Kreft, N. Köster, W. Küper, J. Nieder, and W. Barthlott, "Diversity and biogeography of vascular epiphytes in Western Amazonia, Yasuní, Ecuador," Journal of Biogeography, vol. 31, no. 9, pp. 1463-1476, 2004.

[12] T. G. Laman, "Safety recommendations for climbing rain forest trees with 'single rope technique", Biotropica, vol. 27, no. 3, pp. 406-410, 1995.
[13] T. Alemayehu, Diversity and ecology of vascular epiphytes in Harenna Afro-montane forest, Bale, Ethiopia [M.S. thesis], Addis Ababa University, Addis Ababa, Ethiopia, 2006.

[14] A. Tafa, Diversity of vascular epiphytes along disturbance gradient in Yayu forest, South West Oromia [M.S. thesis], Addis Ababa University, Addis Ababa, Ethiopia, 2010.

[15] P. Hietz and U. Hietz-Seifert, "Composition and ecology of vascular epiphyte communities along an altitudinal gradient in central Veracruz, Mexico," Journal of Vegetation Science, vol. 6, no. 4, pp. 487-498, 1995.

[16] A. Bogh, "Composition and distribution of the vascular epiphytes flora of an Equadorian montane rain forest," Selbyana, vol. 13, pp. 25-34, 1992.

[17] D. Johansson, "Ecology of vascular epiphytes in western African forest," Acta Phytogeographica Suecica, vol. 59, pp. 1-136, 1974.

[18] A. R. Mojiol, A. M. A. Jitinu, A. Adella, G. M. Ganang, and N. Nasly, "Vascular epiphytes diversity at Pusat Sejadi, Kawang forest reserve, Sabah, Malaysia," Journal of Sustainable Development, vol. 2, no. 1, pp. 121-127, 2009.

[19] C. E. Shannon and W. Weaver, The Mathematical Theory of Communication, Illinois Books, Urbana, Ill, USA, 1949.

[20] M. Kent and P. Coker, Vegetation Description and Analysis: A Practical Approach, John Wiley \& Sons, New York, NY, USA, 1992.

[21] J. V. Schneider, Diversity, structure, and biogeography of a successional and mature upper montane rain forest of the Venezuelan Andes [Ph.D. thesis], Johann Wolfgang Goethe-Universität, Frankfurt am Main, Germany, 2001.

[22] P. Hietz, "Diversity and conservation of epiphytes in changing environment lecture," in Proceedings of the International Conference on Biodiversity and Bioresources: Conservation and Utilization, pp. 1-11, 1999.

[23] E. Schuettpelz and D. W. T. Trapnell, "Exceptional epiphyte diversity on a single tree in Costa Rica," Selbyana, vol. 27, pp. 65-71, 2006.

[24] D. H. Benzing, "Vascular epiphytes," in Forest Canopies, M. D. Lowman and H. B. Rinker, Eds., pp. 175-211, Elsevier/Academic Press, San Diego, Calif, USA, 2004.

[25] A. M. Benavides, "Distribution and succession of vascular epiphytes in Colombian Amazonia," Journal of Tropical Ecology, vol. 27, pp. 299-314, 2010.

[26] A.-M. Benavides, J. H. D. Wolf, and J. F. Duivenvoorden, "Recovery and succession of epiphytes in upper Amazonian fallows," Journal of Tropical Ecology, vol. 22, no. 6, pp. 705-717, 2006.

[27] P. Mucunguzi, "Diversity and distribution of vascular epiphytes in the forest lower canopy in Kibale National Park, western Uganda," African Journal of Ecology, vol. 45, no. 3, pp. 120-125, 2007.

[28] A. P. Fordjour, K. A. Anning, G. M. Addo, and F. M. Osei, "Composition and distribution of vascular epiphytes in a tropical semideciduous forest, Ghana," African Journal of Ecology, vol. 47, no. 4, pp. 767-773, 2009.

[29] B. Verdcourt, "Entry for Drynaria volkensii Hieron. [Family Polypodiaceae]," Flora of Tropical East Africa, vol. 1, p. 1, 2001.

[30] M. de Souza Werneck and M. M. do Espírito-Santo, "Species diversity and abundance of vascular epiphytes on Vellozia piresiana in Brazil," Biotropica, vol. 34, no. 1, pp. 51-57, 2002.

[31] R. W. Bussmann, F. Werner, and A. Schaff, Epiphyte Diversity in a Tropical Mountain Ecosystem: The Example of Eastacion Cientifica San Francisco, Ecuador, Universitat Bayreuth, 2000. 
[32] K. C. Burns, "Meta-community structure of vascular epiphytes in a temperate rainforest," Botany, vol. 86, no. 11, pp. 1252-1259, 2008.

[33] A. Flores-Palacios and J. G. García-Franco, "The relationship between tree size and epiphyte species richness: testing four different hypotheses," Journal of Biogeography, vol. 33, no. 2, pp. 323-330, 2006.

[34] S. Laube and G. Zotz, "Long-term changes of the vascular epiphyte assemblage on the palm Socratea exorrhiza in a lowland forest in Panama," Journal of Vegetation Science, vol. 17, no. 3, pp. 307-314, 2006.

[35] H. ter Steege and J. H. C. Cornelissen, "Distribution and ecology of vascular epiphytes in lowland rain forest of Guyana," Biotropica, vol. 21, no. 4, pp. 331-339, 1989. 

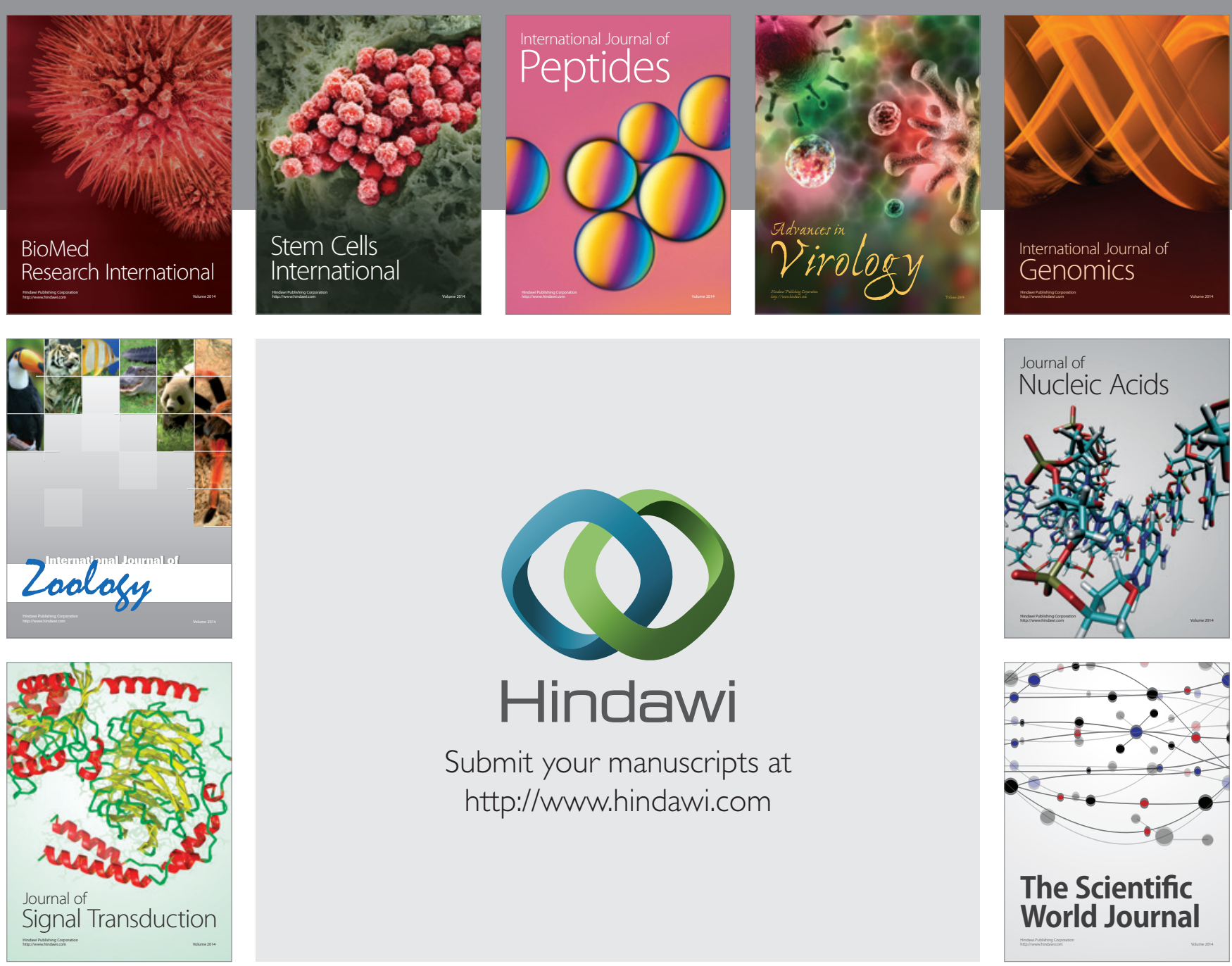

Submit your manuscripts at

http://www.hindawi.com
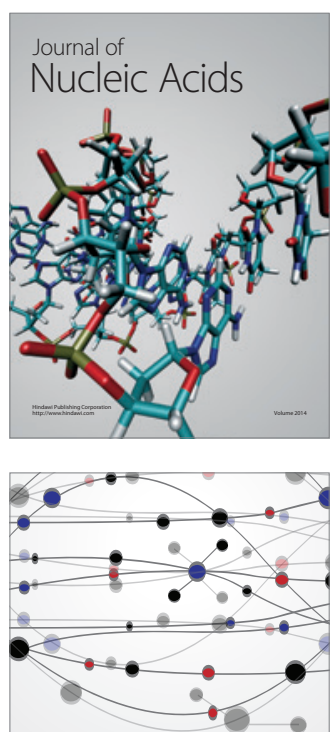

The Scientific World Journal
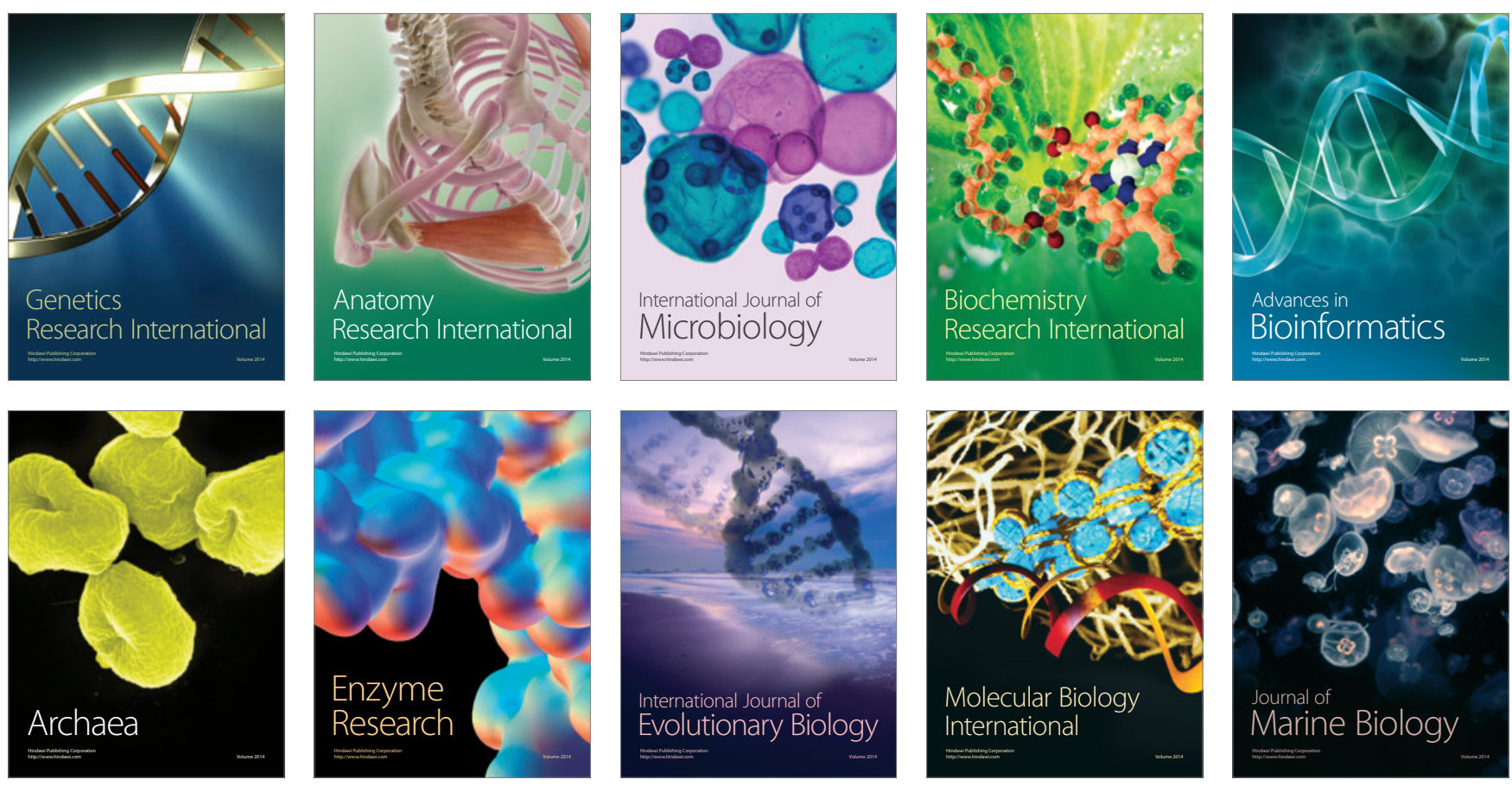